\title{
Susceptibility of Plutella xylostella (Lepidoptera: Plutellidae; Linnaeus 1758) to Beauveria bassiana Bb9205, Metarbizium anisopliae Ma9236 and Heterorhabditis bacteriophora HNI0100
}

\author{
J.P. Correa-Cuadros ${ }^{1}$, M.X. Rodríguez-Bocanegra ${ }^{2}$, A. Sáenz-Aponte ${ }^{1 凶}$
}

\begin{abstract}
The diamondback moth (Plutella xylostella) is a major pest of broccoli worldwide. It mainly causes leaf defoliation and generates annual losses of $80 \%$. In this study we evaluated the susceptibility of P. xylostella to entomopathogens Heterorbabditis bacteriophora HNI0100, Beauveria bassiana Bb9205 and Metarbizium anisopliae Ma9236. The methodology was based on the inoculation of third instar larvae of P. xylostella with 5x101, 1x10², $3 \times 10^{2}, 6 \times 10^{2}$ and $1,2 \times 10^{3} \mathrm{IJs} / \mathrm{cm}^{2}$ of H. bacteriophora HNI0100 and evaluated them after 24,48 and $72 \mathrm{~h}$ and $1 \times 10^{4}, 1 \times 10^{5}, 1 \times 10^{6}, 1 \times 10^{7}$ and $1 \times 10^{8} \mathrm{con} / \mathrm{cm}^{2}$ of B. bassiana $\mathrm{Bb} 9205$ and $M$. anisopliae Ma9236, which were evaluated during two weeks. At a dose of $1,2 \times 10^{3} \mathrm{JIs} / \mathrm{cm}^{2}, P$. xylostella had a susceptibility to $H$. bacteriophora HNI0100 of 91,66\%. Similarly, B. bassiana Bb9205 and M. anisopliae Ma9236 had a mortality of 95,33 and 99,67\% at $1 \times 10^{5} \mathrm{con} / \mathrm{cm}^{2}$. The results suggest that the use of strains of entomopathogenic nematodes and fungi is an innovative alternative for the control of P. xylostella. However, studies on the interaction of nematodes and fungi and Plutella xylostella are necessary.
\end{abstract}

Keywords: Broccoli; biological control; diamondback moth; entomopathogenic fungi; entomopathogenic nematodes.

Edited by Alberto Acosta四

1 Laboratorio de Control Biológico. Grupo de Biología de Plantas y sistemas productivos. Departamento de Biología. Facultad de Ciencias. Pontificia Universidad Javeriana. Bogotá, D.C., Colombia.

2 Unidad de Investigaciones Agropecuarias, UNIDIA. Departamento de Microbiología. Facultad de Ciencias. Pontificia Universidad Javeriana. Bogotá, D.C., Colombia.

Received: 03-02-2014 Accepted: 25-03-2014

Published on line: 16-06-2014

Citation: Correa-Cuadros JP, Rodríguez-Bocanegra MX, Sáenz-Aponte A (2014) Susceptibility of Plutella xylostella (Lepidoptera: Plutellidae; Linnaeus 1758) to Beawveria bassiana Bb9205, Metarbizium anisopliae Ma9236 and Heterorbabditis bacteriophora HNI0100.

Universitas Scientiarum 19(2): 277-285 doi: 10.11144/Javeriana.SC19-2.spxl

Funding: Own resources of Laboratorio de Control Biológico and Unidad de Investigaciones Agropecuarias, Pontificia Universidad Javeriana.

Electronic supplementary material: N/A

\section{Introduction}

One of the main pests affecting broccoli (Brassica oleracea) is the diamondback moth, Plutella xylostella (Linnaeus 1758; Lepidoptera: Plutellidae; Bertolaccini et al. 2010, Sáenz 2012). Worldwide, this pest generates losses of over $80 \%$ (U.S. $\$ 4$ to U.S. $\$ 5$ billion) in annual crop production (Table 1) (Verkerk \& Wright 1996, Sarfraz et al. 2005, Zalucki et al. 2012).

The diamondback moth has a four-stage life cycle (egg, larva, pupa and adult) of 15 to 40 days depending on regional weather conditions; the entire life cycle takes place on the leaves abaxial surface of the host plant (Sarfraz et al. 2005). The egg-stage lasts 3.2 days at $20{ }^{\circ} \mathrm{C}$. During the 15 days of its larval instars 
Table 1. Continents where Brassica oleracea (Broccoli) is grown and annual insecticide application costs (U.S.\$). CI: Cost of insecticide application, and CIPM: Cost of insecticide application with IPM.

\begin{tabular}{|c|c|c|c|}
\hline Continent & $\mathrm{CI}$ & CIPM & Reference \\
\hline Africa & $46,097,772$ & $\$ 11,141,005$ & Zalucki et al. (2012) \\
\hline $\begin{array}{l}\text { Australia and the } \\
\text { Pacific }\end{array}$ & $1,169,364$ & 267,545 & $\begin{array}{l}\text { Goodwin \& Danthanarayana (1984), } \\
\text { Zalucki et al. (2012) }\end{array}$ \\
\hline Asia & $\$ 695,435,398$ & $\$ 161,195,709$ & $\begin{array}{l}\text { Honda (1992), Verkerk \& Wright (1996), } \\
\text { Zalucki et al. (2012) }\end{array}$ \\
\hline Europe & $216,137,670$ & $\$ 52,762,140$ & Zalucki et al. (2012) \\
\hline $\begin{array}{l}\text { North and Central } \\
\text { America }\end{array}$ & $42,129,738$ & $\$ 10,952,758$ & $\begin{array}{l}\text { Madder \& Stemeroff (1998), Dosdall et al. (2004), } \\
\text { Zalucki et al. (2012), Furlong et al. (2013) }\end{array}$ \\
\hline South America & $5,644,128$ & $\$ \quad 1,303,107$ & Talekar \& Shelton (1993), Zalucki et al. (2012) \\
\hline World total & $\$ 1,006,614,070$ & $\$ 237,622,266$ & $\begin{array}{l}\text { Talekar \& Shelton (1993), Zalucki et al. (2012), } \\
\text { Furlong et al. (2013) }\end{array}$ \\
\hline
\end{tabular}

(four instars), the pest causes the greatest damage to broccoli crops (Somvanshi \& Ganguly 2007). White spots on the leaves evidence surperficial mines that alter the photosynthesis process, and cause a decrease in the size and quality of the product intended for consumption (Franco 2001, Schroer et al. 2005, Chavez \& Hurtado 2010). Eighteen days before the adult hatches, the pupa is covered with a silk thread on the abaxial surface of the leaf (Talekar \& Shelton 1993, Chavez \& Hurtado 2010). Adults are nocturnal; males emerge seeking a partner for copulation and are found on the leaves during the day. The average adult female lays 160 to 360 eggs (Furlong et al. 2013).

This insect pest is controlled through the continued use of agrochemicals. A 99-day crop can be treated three to five times with insecticides such as organophosphates, pyrethroids and carbamates (Sarfraz et al. 2005). The indiscriminate use of these products by farmers has led to excessive application of the same and an increase in resistance issues with this lepidopteran pest (Monzón 2001, Sáenz 2012). For this reason, other alternatives of control have been evaluated such as physical barriers, as light and resistant covers to prevent the pest from accessing the plants (Chavez \& Hurtado 2010) or biological control using parasitoids such as Diadegma insulare or Cotesia plutellae or entomopathogenic fungi and nematodes, which have shown significant advance in managing the diamondback moth (Sarfraz et al. 2005, Schroer et al. 2005, Bertolaccini et al. 2010).

With a 85\% mortality, the entomopathogenic nematode, Heterorbabditis bacteriophora (Poinar 1976) (Rhabditida: Heterorhabditidae) is one of the species with the greatest potential to control P. xylostella (Shinde \& Singh 2000, Somvanshi \& Ganguly 2007). This nematode species is a cruise-type forager that can enter through the anus, spiracles or cuticle (Sánchez 2002). It is hermaphrodite during the first generation of its life cycle and has a tooth that allows it to perforate any insect cuticle, which gives it a competitive advantage over other biocontrol agents (Sáenz \& Lopez 2010).

Entomopathogenic fungi, Beauveria bassiana (Balsamo-Crivelli) Vuillemin (Cordycipitaceae) and Metarbizium anisopliae (Metschnikoff) Sorokin (Clavicipitaceae) have been widely used to control P. xylostella (Loc \& Chi 2007), producing over 50\% mortality (Furlong \& Pell 2001, Pucheta et al. 2006, 
Hui Wu et al. 2010). Although they do not enter through the mouth or anus, they have the ability to adhere to the insect cuticle and penetrate it using cuticle-degrading enzymes to carry out an effective colonization (Loc \& Chi 2007).

The success of using entomopathogenic nematodes and fungi in biological control strategies depends on the strains of natural enemies and their relationship with the pest (Sarfraz et al. 2005). The populations of $M$. anisopliae, B. bassiana and H. bacteriophora differ genetically and biologically depending on the region in which they are isolated; therefore, it is necessary to assess their virulence and pathogenicity to the pest to be controlled (Furlong et al. 2013).

The objective of this study was to assess the susceptibility of P.xylostella to H. bacteriophora HNI0100, B. bassiana Bb9205 and M. anisopliae Ma9236 for future studies on the interaction of fungi and nematodes to control diamondback moth.

\section{Materials and methods}

Entomopathogens: H. bacteriophora HNI0100, M. anisopliae Ma9236 and B. bassiana Bb9205. After screening different strains of Steinernematidae and Heterorhabditidae, entomopathogenic nematode H. bacteriophora HNI0100 was used for the laboratory tests (Delgado-Ochica \& Sáenz 2012). The Biological Control Laboratory at Pontificia Universidad Javeriana provided the infective juveniles, which were multiplied in vivo by infecting last instar larvae of Galleria mellonella (Linnaeus 1756) (Lepidoptera: Pyralidae) following the methodology of Kaya \& Stock (1997). The entomopathogenic fungi B. bassiana Bb9205 and M. anisopliae Ma9236 were obtained from the Laboratorio de Control de Calidad de Bioinsumos Agrícolas Control de Bioinsumos Disciplina de Entomología, Cenicafé, Chinchiná - Caldas - Colombia. The fungi were activated by infecting P. xylostella. For the optimal growth and production of conidia, the reactivated strains were grown in PDA (potato dextrose agar) and oatmeal agar for 15 days at $25^{\circ} \mathrm{C}$.

Entomopathogenic Evaluation: The susceptibility of P. xylostella to H. bacteriophora HNI0100, B. bassiana Bb9205 and M. anisopliae Ma9236 was evaluated by transferring one larva of third instar to $2 \mathrm{oz}$ plastic containers, each one containing $5 \mathrm{~g}$ of broccoli leaf and $60 \mathrm{~g}$ of sterile river sand (Table 2). The infective juveniles (IJs) were suspended in distilled water with Tween $80(0.1 \% \mathrm{v} / \mathrm{v})$ and inoculated over the sand and broccoli leaf. Larvae mortality by entomopathogenic nematodes was evaluated during 24, 48 and 72 hours. Subsequently, once dead, the larvae were transferred to White traps to recover infective juveniles. Fungal conidia were suspended in saline solution with Tween $80(0.1 \% \mathrm{v} / \mathrm{v})$ and inoculated over the sand and broccoli leaf. Larvae mortality by entomopathogenic fungi was evaluated during two weeks.

Statistical Analysis: P. xylostella mortality percentages were tested for variance homogeneity (Levene) and normality (Kolmogorov-Smirnov); the assumptions for parametric data were met, demonstrating that treatment variances were the same and their errors had a normal

Table 2. Treatments and doses used for experimental design of Plutella xylostella susceptibility to entomopathogens H. bacteriophora HNI0100, B. bassiana Bb9205 and M. anisopliae Ma9236.

\begin{tabular}{cccc}
\hline Treatment & $\begin{array}{c}\text { H. bacteriophora HNI0100 } \\
\text { P. xylostella }\left(\mathrm{JIs} / \mathrm{cm}^{2}\right)\end{array}$ & $\begin{array}{c}\text { B. bassiana } \mathrm{Bb} 9205+ \\
\text { P. xylostella }\left(\mathrm{con} / \mathrm{cm}^{2}\right)\end{array}$ & $\begin{array}{c}\text { M. anisopliae Ma9236 }+ \\
\text { P. xylostella }\left(\mathbf{c o n} / \mathrm{cm}^{2}\right)\end{array}$ \\
\hline 1 & $5 \times 10^{1}$ & $1 \times 10^{4}$ & $1 \times 10^{4}$ \\
2 & $1 \times 10^{2}$ & $1 \times 10^{5}$ & $1 \times 10^{5}$ \\
3 & $3 \times 10^{2}$ & $1 \times 10^{6}$ & $1 \times 10^{6}$ \\
4 & $6 \times 10^{2}$ & $1 \times 10^{7}$ & $1 \times 10^{7}$ \\
5 & $1,2 \times 10^{3}$ & $1 \times 10^{8}$ & $1 \times 10^{8}$ \\
6 & 0 & 0 & 0 \\
\hline
\end{tabular}


distribution. A univariate ANOVA with a factorial arrangement was used to determine whether dose and time means were the same or different in relation to the mortality percentage of each test (entomopathogenic nematodes and fungi) and to determine the interaction of both factors. Subsequently, multiple comparisons using Tukey and Scheffe tests were performed, employing a 95\% probability, to identify the dose with the highest mortality of P. xylostella larvae, as well as the time during which the highest mortality occurred. The tests were performed using Statistix 10 software.

\section{Results}

Third instar larvae of P. xylostella were susceptible to H. bacteriophora $\mathrm{HNI} 0100$ with significant differences between doses $(\mathrm{F}=5002.48, \mathrm{p}=0.0000)$ and time $(\mathrm{F}=2614.75, \mathrm{p}=0.0000)$ (Figure 1a). The post-hoc tests indicated that the dose with the highest mortality was $1,2 \times 10^{3} \mathrm{IJs} / \mathrm{cm}^{2}$ with a percentage of $91,66 \%$. Similarly, the highest larvae mortality occurred at 48 and 72 hours post-inoculation. This experiment replicated the interaction between dose and time $(\mathrm{F}=205.71, \mathrm{p}=0.0000)$ mentioned by Goettel et al. (1993). Larvae cavaders displayed a yellow-ocher coloration, which is an indicative of a IJs infection (Figure 2a). Additionally, the IJs migrated from cadavers (Figure 2b).

Third instar larvae were susceptible to $M$. anisopliae Ma9236 (Figure 2c) and B. bassiana Bb9205 (Figure 2d and 2e), presenting a characteristic fungal symptomatology. Significant differences between doses $(\mathrm{F}=222.06, \mathrm{p}=0.0000)$ and time $(\mathrm{F}=274.57, \mathrm{p}=0.0000)$ were found for B. bassiana Bb9205 (Figure 1b), M. anisopliae Ma9236 behaved equally with dose $(\mathrm{F}=1529.34, \mathrm{p}=0.0000)$ and time $(\mathrm{F}=11060.65, \mathrm{p}=0.0000)$ (Figure 1c).

The highest mortality produced by $B$. bassiana Bb9205 (95,33\%) was at a dose of $1 \times 10^{5} \mathrm{con} / \mathrm{cm}^{2} 15$ days after inoculation, and by $M$. anisopliae Ma9236 $(99,67 \%)$ was at a dose of $1 \times 10^{5} \mathrm{con} / \mathrm{cm}^{2} 15$ days after inoculation. The interaction between dose and time for B. bassiana $(\mathrm{F}=32.15, \mathrm{p}=0.0000)$ and $M$. anisopliae $(\mathrm{F}=171.94, \mathrm{p}=0.0000)$ suggests a trend of increasing mortality over time.
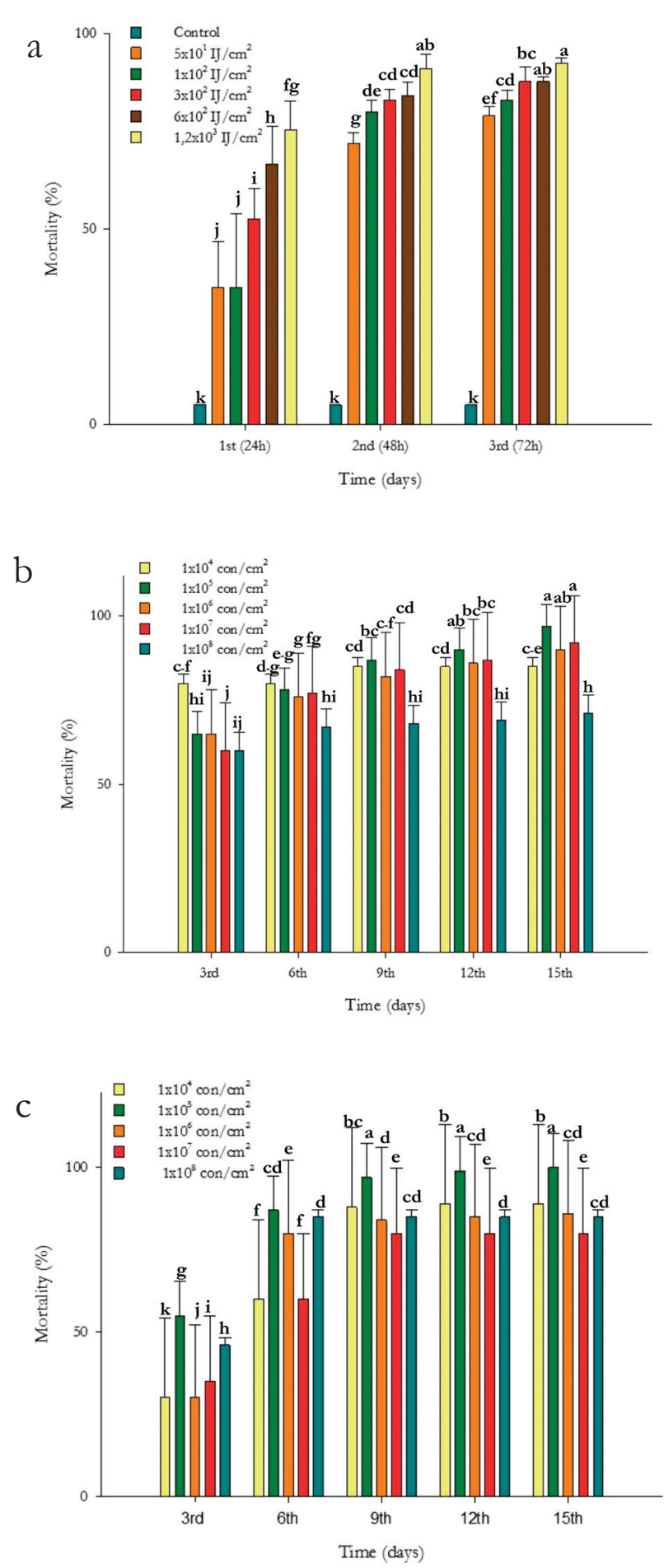

Fig. 1. a. Susceptibility of P. xylostella to H. bacteriophora HNI0100, B. bassiana Bb9205 and M. anisopliae Ma9236 in time. a. H. bacteriophora HNI0100. b. B. bassiana Bb9205. c. M. anisopliae Ma9236. Ratios were calculated for each treatment and used to determine the standard error. Treatments with the same letter had no significant difference $(\mathrm{p}<0.05)$. 


\section{Discussion}

Third instar larvae of P. xylostella were susceptible to H. bacteriophora HNI0100. The highest mortality, a percentage of $91,66 \%$, occurred with the dose of $1,2 \times 10^{3} \mathrm{IJs} / \mathrm{cm}^{2}$ at 72 hours post-inoculation. A study by Sáenz (2012) obtained similar data, the mortality rate in this study was of $95 \%$. Ratansinghe \& Hauge
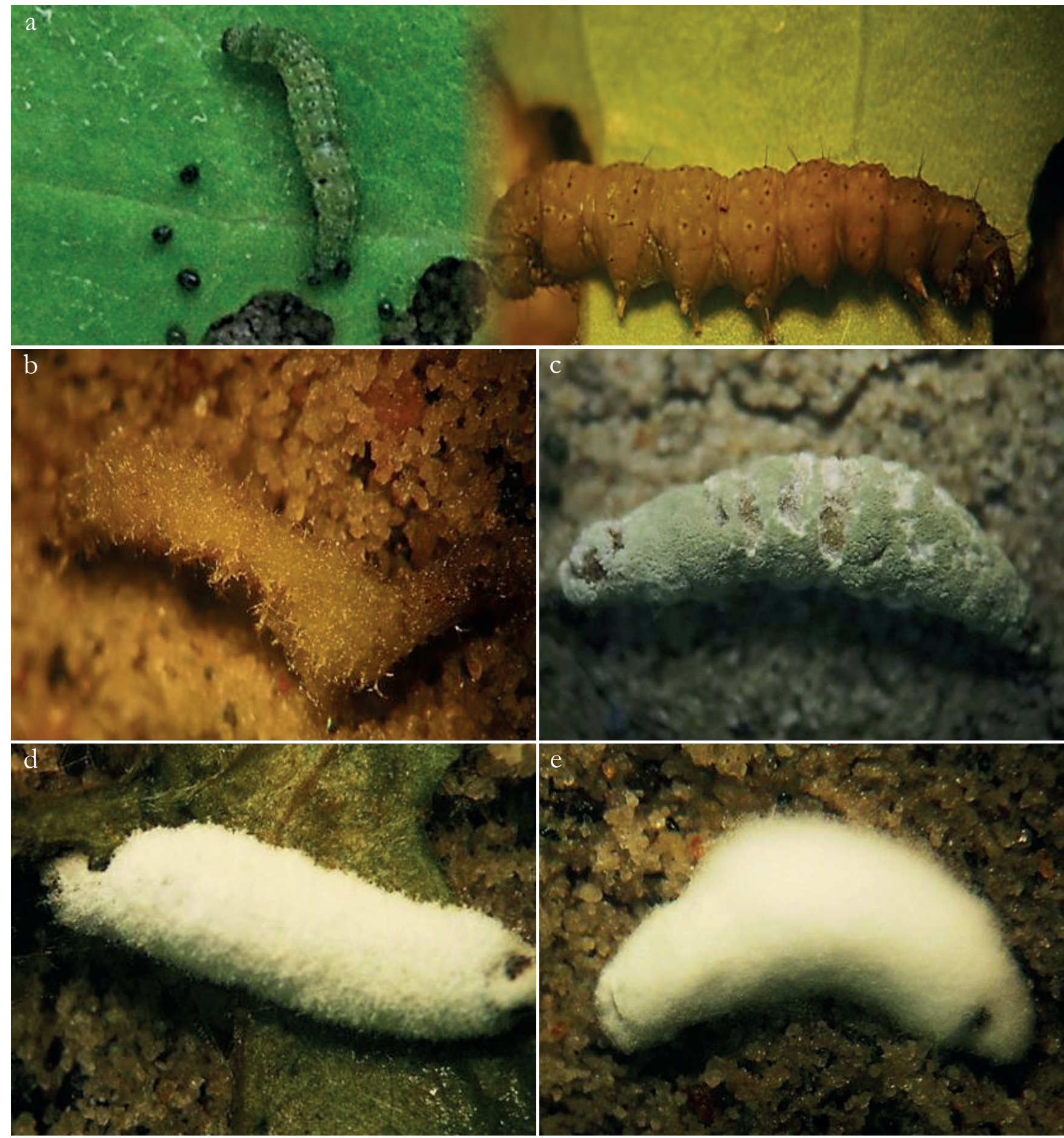

Fig. 2. Susceptibility of P. xylostella to H. bacteriophora HNI0100, B. bassiana Bb9205 and M. anisopliae Ma9236. a. Control larva and larva killed by H. bacteriophora HNI0100 with yellow ocher coloration. b. Larva killed by entomopathogenic nematodes emerging from host. c. Larva killed by M. anisopliae Ma9236 with green mycelium. d. - e. Larva killed by B. bassiana Bb9205 with white mycelium. 
(1995) and Nyasani et al. (2008 a and b) also obtained mortality rates of 85 to $95 \%$ with $H$. indica. The results obtained by Salem et al. (2007) demonstrated that the percentage of mortality increased with time, establishing that the mortality generated in the first 48 hours is due to a mutualistic relationship with Photorbabdus luminescens (Poinar 1976), which gives the nematode a competitive advantage allowing it to kill its host quickly (Mason \& Wright 2000, Sáenz 2012). According to Mason \& Wright (1997) and Baur et al. (1995), the yellow-ocher coloration displayed by $P$. xylostella after infection by $H$. bacteriophora HNI0100 is not the characteristic symptomatology for Heterorhabditidae, which usually display a reddish hue. This divergence is attributed to the insect's original color (green), the concentration of bacterial cells of $P$. luminescens in each infective juvenile that enters the larva (30-200 IJs), the concentration of bacteria in the insect's hemolymph and the refraction of light on the cuticle (Silva et al. 2002, Waterfield et al. 2009). The larvae had a symptomatology characteristic of infection by nematodes, displaying flaccidity and little mobility, as reported by Nyasani et al. (2008).

Third instar larvae were susceptible to B. bassiana Bb9205 and M. anisopliae Ma9236. Both fungi had the highest mortality at a dose of $1 \times 10^{5} \mathrm{con} / \mathrm{cm}^{2}$ on day 15 after inoculation; this is comparable to results obtained by Franco (2001), who establish that the percentage of mortality increases with time, and is corroborated by studies by Loc \& Chi (2007), Thuy (2001) Butt \& Goettel (2000), that conclude that fungal pathogenicity is characterized by a gradual increase in mortality with extended exposure time. According to Quesada-Moraga \& Vey (2004), Hui Wu et al. (2010) and Anaisie et al. (2011), concentrations of $1 \times 10^{5} \mathrm{con} / \mathrm{cm}^{2}$ are low to cause a mortality percentage exceeding $60 \%$ in P. xylostella; these authors recommend the use of concentrations in excess of $1 \times 10^{9} \mathrm{con} / \mathrm{cm}^{2}$ to produce a larval mortality of $80 \%$. This study demonstrates that a high mortality can be obtained at low-doses, depending on the species and strain of the entomopathogenic fungus (Roy \& Pell 2000, Furlong \& Pell 2001, Sun et al. 2002, Furlong 2004). Sarfraz et al. (2005) indicate that the success of biological control strategies depends on the accurate identification of natural enemies and association with the strain; misidentifications can prompt the failure of the pest management program. Ibrahim \& Low (1993) and Shelton et al. (1998) state that strains of entomopathogenic fungi produce different responses in mortality of individuals because their virulence and pathogenicity are not the same. By conducting tests on P. xylostella with six isolates of B. bassiana and two of $M$. anisopliae, Godonou et al. (2009) found that the strain with the highest mortality (94\%) was Bba5653, establishing that the percentage and death rate of the pest can be variable. A study by Vandenberg et al. (1998) determined that the survival times for $P$. xylostella larvae, inoculated at different doses, were variable for two strains of $B$. bassiana, pathogenicity decreased with an increased dose, which agrees with our results. They also established that survival times and mortality vary between the two isolates, this is related to strains and their virulence.

The relationship between doses, mortality, biological controllers and pest generally responds to a positive correlation between the dose and the pathogen ability to kill the pest (Pena et al. 1991, Ferron 1981, Butt \& Goettel 2000). In this study, the nematodes dose with the highest mortality was the most concentrated $\left(1,2 \times 10^{3} \mathrm{JIs} / \mathrm{cm}^{2}\right)$, which may suggest a positive correlation between dose and mortality. Contrary, B. bassiana Bb9205 and M. anisopliae Ma9236 showed a possible negative correlation, thus $1 \times 10^{5} \mathrm{con} / \mathrm{cm}^{2}$, the dose with de highest mortality, is one of the lowest doses tested. This result may be explained by Butt \& Goettel (2000), who mentioned that for entomopathogenic fungi there is a threshold dose to kill a pest, nevertheless the exact nature of this relationship has not been defined yet. Studies by Goettel et al. (1993) and Vandenberg et al. (1998) report a negative correlation between doses and mortality at the highest concentrations, occurring an autoinhibition; which may explain our mortality results for the fungal strains.

This study is of high importance as it gives way to establish interactions between fungi and nematodes that can generate possible synergy or additivity to pest mortality.

\section{Conclusion}

The inoculations of entomopathogenic nematodes $\left(1,2 \times 10^{3} \mathrm{JIs} / \mathrm{cm}^{2}\right)$ and fungi $\left(1 \times 10^{5} \mathrm{con} / \mathrm{cm}^{2}\right)$ cause 
mortality rates exceeding $90 \%$ for $P$. xylostella, in comparison with the majority of studies using higher concentrations to achieve the same mortality. The use of Colombian strains of $H$. bacteriophora HNI0100, B. bassiana Bb9205 and M. anisopliae Ma9236 is an innovative alternative for the control of $P$. xylostella and should be considered a management strategy in broccoli production.

\section{Acknowledgements}

The authors wish to acknowledge the support of the Centro de Bio-Sistemas (C-BIOS) of University Jorge Tadeo Lozano and Pontificia Univerisidad Javeriana.

\section{Conflicts of interest}

The authors declare that there are no conflicts of interest regarding the results published in this work.

\section{References}

Anaisie P, Eziah V, Owusu E (2011) The potential of indigenous entomopathogenic fungi for the management of the diamondback moth, Plutella xylostella L. (Lepidoptera: Yponomeutidae) in Ghana. Journal of Biochemistry and Bioinformatics. 1 (10) 275-281

Baur M, Kaya H, Thurston G (1995) Factors affecting entomopathogenic nematode infection of Plutella xylostella on a leaf surface. Entomologia Experimentalis et Applicata 77.3 239-250

Bertolaccin I, Sánchez D, Arregui C (2010) Incidencia de algunos factores naturales de mortalidad de Plutella xylostella (L.) (Lepidoptera: Plutellidae), en el área centroeste de Santa Fe, Argentina. Horticultura Argentina. 29 (8) 20-24

Butt T, Goettel M (2000) Bioessays of entomopathogenous fungi. In: Navon, A., Ascher, K.R.S. (Eds.), Bioessays of Entomopathogenic Microbes and Nematodes. 141191

Chávez G, Hurtado R (2010) El manejo integrado de Plutella xylostella en brócoli, coliflor y repollo con combinaciones selectas de microtúneles, nematodo entomopatógeno, refugios, y e insecticida Rynaxypyr en Zamorano, Honduras. Tesis de Doctorado. Carrea de Ciencia y Producción Agropecuaria. ZamoranoHonduras

Delgado-Ochica Y, Sáenz A (2012) Virulencia, producción y desplazamiento de nematodos entomopatógenos sobre larvas del picudo de la guayaba Conotrachelus psidii Marshall (Coleoptera: Curculionidae) en laboratorio. Universitas Scientiarum. 17 (3) 283-290
Dosdall L M, Mason P G, Olfert O, Kaminski L, Keddie B A (2004) The origins of infestations of diamondback moth, Plutella xylostella (L.), in canola in western Canada. In: Endersby NM, Ridland PM, editors. The management of diamondback moth and other crucifer pests. Proceedings of the Fourth International Workshop, Melbourne. Melbourne, Australia: Department of Natural Resources and Environment. 95-100

Ferron P (1981) Pest control by the fungi Beauveria and Metarbizium. In: Burges, H.D. (Ed.), Microbial Control of Pests and Diseases 1970-1980. Academic Press, London 465-482

Franco K (2001) Evaluación de tres cepas de hongos entomopatógenos para el control de Plutella xylostella (L.) (Lepidoptera: Plutellidae) en condiciones de laboratorio. Tesis de Doctorado. Universidad Earth. Costa Rica

Furlong M J (2004) Infection by the immature stages of Diadegma semiclausum, an endolarval parasitoid of the diamondback moth by Beauveria bassiana. Journal of Invertebrate Pathology. 85 52-55

Furlong M,Wright D, Dosdall Ll (2013) Diamondback Moth Ecology and Management: Problems, Progress, and Prospects. Annual Reviews Entomology. 58 517-41

Furlong M., Pell J (2001) Horizontal Transmission of Entomopathogenic Fungi by the Diamondback Moth. Biological Control. 22 288-299

Godonou I, James B, Atcha-Ahowe C, Vodouhe S, Kooyman C, Ahanche de A, Korie S (2009) Potential of Beauveria bassiana and Metarhizium anisopliae isolates from Benin to control Plutella xylostella L. (Lepidoptera: Plutellidae). Crop Protection 28 220-224

Goettel M S, Vandenberg J D, Duke G M, Schaalje G B (1993). Susceptibility to chalkbrood of alfalfa leafcutter bees, Megachile rotundata, reared on natural and artificial provisions. Journal of Invertebrate Pathology 61 58-61

Goodwin S, Danthanarayana W (1984) Flight activity of Plutella xylostella (L.) (Lepidoptera: Yponomeutidae). Journal of the Australian Entomological Society 23 235-240

Honda K (1992) Hibernation and migration of the diamondback moth in north Japan. In: Talekar NS, editor. Diamondback moth and other crucifer pests. Proceedings of the Second International Workshop, Tainan, Taiwan: Asian Vegetable Research and Development Center. 43-50

Hui Wu J, Ali S, Xiang Ren S (2010) Evaluation of Chitinase from Metarbizium anisopliae as Biopesticide Against Plutella xylostella. Pakistan J. Zool. 42 (5) 521-528

Ibrahim Y B, W Low (1993) Potential of mass-production and field efficacy of isolates of the entomopathogenic fungi Beauveria bassiana and Paecilomyces fumosoroseus against Plutella xylostella. International Journal of Pest Management $39.3288-292$ 
Kaya H, Stock P (1997) Techniques of insect nematology. In: Manual of techniques in insect pathology. Lawrence Lacey (Eds). Biological Techniques Series. Academic Press, San Diego. Cap. VI. 1- 409

Loc NT, Chi V T B (2007) Biocontrol potential of Metarbizium anisopliae and Beawveria bassiana against diamondback moth, Plutella xylostella. Omonrice. 15 86-93

Madder D J, Stemeroff M (1988) The economics of insect control on wheat, corn, and canola. Bulletin of the Entomological Society of Canada (Supplement) 20-22

Mason J M, Wright D J (1997) Potential for the Control of Plutella xylostella Larvae with Entomopathogenic Nematodes. Journal of invertebrate pathology 70.3 234-242

Mason J, Wright D (2000) Entomopathogenic nematodes against foliage feeding crucifer pests in the tropics. In: Proceedings: The Management of Diamondback Moth and Other Crucifers Pest. Pp 328- 331

Monzón A (2001) Producción, uso y control de calidad de hongos entomopatógenos en Nicaragua. Manejo Integrado de Plagas. 63 95-103

Nyasani J, Kimenju F, Olubayo S, Shibairo A, Mutua G (2008 a) Ocurrence of entomopathogenic nematodes and their potencial in the management of diamondback moth in Kale. Asian Journal of Plant Sciencies. 7 (3) 314-318

Nyasani J, Kimenju J, Olubayo S, Wilson M (2008 b) Laboratory and field investigations using indigenous entomopathogenic nematodes for biological control of Plutella xylostella in Kenya. Internacional Journal of Pest Management. 54 (4) 355-361

Pena J E, Duncan R, Martin R (1991) Biological control of Cosmopolites sordidus in Florida. In: Gold, C.S., Gemmill, B. (Eds.), Biological and Integrated Control of Highland Banana and Plantain Pests and Diseases, Proceedings of Research Coordination Meeting. 124-139

Pucheta M, Flores A, Rodríguez S, De la Torre M (2006) Mecanismos de acción de los hongos entomopatógenos. Interciencia 31 (12) pp 1-20

Quesada-Moraga E, Vey A (2004) Bassiacridin, a protein toxic for locusts secreted by the entomopathogenic fungus Beawveria bassiana. Mycological Research. 108 (4) 441-452

Ratansinghe G, Hauge N (1995) The susceptibility of diamond back moth Plutella xylostella (Lepidoptera: Yponomeutidae) to entomopathogenic nematodes. AfroAsian Journal of Nematology. 5 20-23

Roy H, Pell J (2000) Interactions Between Entomopathogenic Fungi and Other Natural Enemies: Implications for Biological Control. Biocontrol Science and Technology. 10737 752

Sáenz A (2012) Susceptibilidad de Plutella xylostella a Heterorhabditissp. SL0708 (Rhabditida:Heterorhabditidae). Revista Colombiana de Entomología. 38 (1) 29-31
Sáenz A, López J (2010) Ciclo de vida y patogenicidad del aislamiento nativo Heterorhabditis sp. SL0708 (Rhabditida: Heterorhabditidae). Revista Colombiana de Entomología. 37 43-47

Salem S, Abdel-Rahman H, Zebitz C, Saleh M, Fawkia I, El-Kholy M (2007) Evaluation of Entomopathogenic Nematodes in Controlling Some Cabbage Pests. Journal of Applied Sciences Research. 3 (4) 323-328

Sánchez L (2002) Heterorbabditis bacteriophora HC1. Estrategia de desarrollo como agente de control biológico de plagas insectiles. Tesis de Doctorado. Universidad Agraria de la Habana. Centro Nacional de Sanidad Agropecuaria

Sarfraz M, Keddie A, Dosdall Ll (2005) Biological control of the diamondback moth, Plutella xylostella: A review. Biocontrol Science and Technology. 15 (8) 763-789

Schroer S, Xiaoli Y, Ehlers R (2005) Evaluation of adjuvants for foliar application of Steinernema carpocapsae against larvae of the diamondback moth (Plutella xylostella). Nematology 7.1 37-44

Shelton A M, Vandenberg J D, Ramos M, Wilsey W T (1998) Efficacy and persistence of Beauveria bassiana and other fungi for control of diamondback moth (Lepidoptera: Plutellidae) on cabbage seedlings. Journal of Entomological Science 33.2 142-151

Shinde S, Singh N P (2000) Susceptibility of diamondback moth, Plutella xylostella L. to entomopathogenic nematodes. Indian Journal of Experimental Biology. 38 956959

Silva C, Waterfield N, Daborn P, Dean P, Chilver T, Au C, Sharma S, Potter U, Reynolds S, H. ffrench-Constant R (2002) Bacterial infection of a model insect: Photorbabdus luminescens and Manduca sexta. Cellular Microbiology. 4 (6) $329-339$

Somvanshi V S, Ganguly S (2007) Efficacy of foliar applications of entomopathogenic nematodes against the crucifer diamondback moth, Plutella xylostella- A review. Nematol. Medit. 35 5-14

Sun J, Fuxa J, Henderson G (2002) Sporulation of Metarbizium anisopliae and Beawveria bassiana on Coptotermes formosanus and in vitro. Journal of Invertebrate Patbology. 81 78-85

Talekar N S, Shelton A M (1993) Biology, ecology, and management of the diamondback moth. Annual Review of Entomology 38 275-301

Thuy P T, Thanh N T, Dinh N V (2001) Effect of Beawveria bassiana conidia suspension on insect pests. In: Proceedings, International Workshop On Biology. 436 - 441

Vandenberg J D, Ramos M, Altre J (1998) Doseresponse and age-and temperature-related susceptibility of the diamondback moth (Lepidoptera: Plutellidae) to two isolates of Beawveria bassiana (Hyphomycetes: Moniliaceae). Environmental Entomology 27.4 1017-1021 
Verkerk R, Wright D J (1996) Multitrophic interactions and management of the diamondback moth: A review. Bulletin of Entomological Research. 86. 205-216

Waterfield N, Chiche T, Clarke D (2009) Photorhabdus and a Host of Hosts. Annual Review of Microbiology. 63. 557-574
Zalucki M P, Shabbir A, Silva R, Adamson D, Shu-Sheng L, Furlong M (2012) Estimating the Economic Cost of One of the World's Major Insect Pests, Plutella xylostella (Lepidoptera: Plutellidae): Just How Long is a Piece of String? Journal of Economic Entomology 105(4) 1115-1129
Susceptibilidad de Plutella xylostella (Lepidoptera: Plutellidae; Linnaeus 1758) a Beauveria bassiana Bb9205, Metarbizium anisopliae Ma9236 y Heterorhabditis bacteriophora HNI0100

Resumen. La palomilla dorso de diamante (Plutella xylostella) es una de las principales plagas del cultivo de brócoli (Brassica oleracea) en el mundo. El principal daño es la defoliación de las hojas, generando pérdidas anuales del $80 \%$. El objetivo de este estudio fue evaluar la susceptibilidad de $P$. xylostella a los entomopatógenos Heterorbabditis bacteriophora HNI0100, Beawveria bassiana Bb9205 y Metarbizium anisopliae Ma9236. La metodología se basó en la inoculación de $5 \times 10^{1}, 1 \times 10^{2}, 3 \times 10^{2}, 6 \times 10^{2}$ y 1,2×10 $\mathrm{JIs} / \mathrm{cm}^{2}$ en larvas de tercer instar de $P$. xylostella evaluada a las 24,48 y $72 \mathrm{~h}$ y $1 \times 10^{4}, 1 \times 10^{5}, 1 \times 10^{6}, 1 \times 10^{7}$ y $1 \times 10^{8} \mathrm{con} / \mathrm{cm}^{2}$ de B. bassiana y $M$. anisopliae evaluadas durante dos semanas. Los resultados mostraron que $P$. xylostella fue susceptible a $H$. bacteriophora HNI0100 con una tasa de mortalidad del 91,66\% a dosis de $1,2 \times 10^{3} \mathrm{JIs} / \mathrm{cm}^{2}$. Así mismo, B. bassiana Bb9205 y M. anisopliae Ma9236 generaron 95,33 y 99,67\% de mortalidad con la dosis de $1 \times 10^{5} \mathrm{con} / \mathrm{cm}^{2}$. El uso de nematodos y hongos entomopatógenos es una alternativa innovadora para el control de P. xylostella, sin embargo, se requiere estudiar su interacción para el control de este insecto plaga.

Palabras clave: Brócoli; control biológico; hongos entomopatógenos; nematodos entomopatógenos; palomilla dorso de diamante.
Susceptibilidade de Plutella xylostella (Lepidoptera: Plutellidae; Linnaeus 1758) a Beauveria bassiana Bb9205, Metarbizium anisopliae Ma9236 e Heterorhabditis bacteriophora HNI0100

Resumo. A mariposa dorso de diamante Plutella xylostella é uma das principais pragas do cultivo dos brócolos (Brassica oleracea) no mundo. O principal dano é o desfolhamento das folhas, gerando perdas anuais de $80 \%$. O objetivo deste estudo foi avaliar a suceptibilidade da $P$. xylostella aos entomopatógenos Heterorbabditis bacteriophora HNI0100, Beaweria bassiana Bb9205 e Metarbizium anisopliae Ma9236. A metodologia baseou-se na inoculação de $5 \times 10^{1}, 1 \times 10^{2}, 3 \times 10^{2}, 6 \times 10^{2}$ y $1,2 \times 10^{3} \mathrm{JIs} / \mathrm{cm}^{2} \mathrm{em}$ larvas do terceiro instar de P. xylostella avaliada às $24,48 \mathrm{e} 72 \mathrm{~h}$ e $1 \times 10^{4}, 1 \times 10^{5}, 1 \times 10^{6}, 1 \times 10^{7}$ e $1 \times 10^{8} \mathrm{con} / \mathrm{cm}^{2}$ de B. bassiana e $M$. anisopliae avaliadas durante 2 semanas. Os resultados mostraram que P. xylostella foi susceptível a H. bacteriophora HNI0100 com uma taxa de mortalidade de $91,66 \%$ com a dose de $1,2 \times 10^{3} \mathrm{JIs} /$ $\mathrm{cm}^{2}$. Desta forma, B. bassiana Bb9205 e M. anisopliae Ma9236 geraram 95,33 é $99,67 \%$ de mortalidade com a dose de $1 \times 10^{5}$ con $/ \mathrm{cm}^{2}$. O uso de estirpes colombianas de nematóides e fungos entomopatógenos é uma alternativa inovadora para o controlo de $P$. xylostella. Ainda se requer estudar a interação entre fungos e nematóides em Plutella xylostella.

Palavras-chave: Brócolos; controlo biológico; fungos entomopatógenos; nematóides entomopatógenos; mariposa dorso de diamante. 